\begin{tabular}{|c|c|c|}
\hline 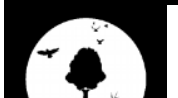 & Our & $\begin{array}{l}\text { ISSN: 1991-2951 (Print) } \\
\text { ISSN: 2091-2781 (Online) }\end{array}$ \\
\hline $\begin{array}{l}\text { Nature Conservation \& } \\
\text { Health Care Counclil } \\
\text { Blratrogac Nopal }\end{array}$ & Journal homepage: http://nepjol.info/index.php/ON & (cc) \\
\hline
\end{tabular}

\title{
Ichthyo-faunal diversity of Morang district, Nepal
}

\author{
Bharat Raj Subba $^{1 *}$, Nelson Pokharel ${ }^{2}$ and Manish Raj Pandey ${ }^{3}$ \\ ${ }^{1}$ Department of Zoology, Post Graduate Campus, T.U., Biratnagar, Nepal \\ ${ }^{2}$ Directorate of Fisheries Development, Balaju, Kathmandu, Nepal \\ ${ }^{3}$ National Trust for Nature Conservation, Lalitpur, Nepal \\ *E-mail:subbabharatraj@gmail.com
}

\begin{abstract}
The present paper attempts to report a total of 118 fish species spread over 11 orders, 26 families and 64 genera inhabited indifferent water bodies viz, rivers, reservoirs, streams, ponds, lakes, canals, ditches, paddy fields of Morang district, collected during a one-year survey. The order Cypriniformes is the richest one among 11 orders that comprises 59 species followed by Siluriformes having 31 and Perciformes with 19 representatives, respectively. Orders Anguilliformes, Osteoglossiformes, Beloniformes, Cyprinodontiformes, Synbranchiformes and Tetraodontiformes have only one representative. Olyra longicaudata is the new report from Morang district and the second report from Nepal. Besides this, other hill-stream fishes viz., Pseudecheneis sulcatus, Schizothorax plagiostomus, Schistura savona and Neolissochilus hexagonolepis recorded during the survey, also have not been previously reported from this district.
\end{abstract}

Key words: Fish diversity, Betna Simsar, Chisang Khola, meristic count

DOI: http://dx.doi.org/10.3126/on.v15i1-2.18794

Manuscript details: Received: 05.06.2017 / Accepted: 19.11.2017

Citation: Subba, B.R., N. Pokharel and M.R. Pandey 2017. Ichthyo-faunal diversity of Morang district, Nepal. Our Nature 15(1-2): 5567. DOI: http://dx.doi.org/10.3126/on.v15i1-2.18794

Copyright: (C) Subba et al., 2017. Creative Commons Attribution - Non Commercial 4.0 International License.

\section{Introduction}

Nepal is endowed with many forms of water resources scattered throughout the country in the form of rivers, streams, lakes, ponds, reservoirs, wetlands, swamps and paddy fields (Petr and Swar, 2002). These water resources provide suitable freshwater aquatic habitats for the survival of aquatic animals and plants including freshwater fishes of varied behaviors. Fishes are the most familiar aquatic lower vertebrates and show their diversity throughout the world.

The inception of taxonomic work on fishes of Nepal goes back towards eighteenth century when Hamilton (1822) made the first report of fishes of Nepal. Hickel (1979), Günther (1861) and Day (1869) made expeditions to survey fish of India and its adjoining countries. Hora (1921) reported some rare fishes of Eastern Himalayas. After nearly thirty nine years or so, other ichthyologists have made attempts to explore fishes from freshwater of Nepal. Their unfailing regular addresses to the fishes of Nepal have delineated some fish species along their habitats and made literature concerned rich for the workers to follow up. Among a good numbers of dedicated contributors to the taxonomical works on fish of Nepal, the works of Taft (1955), Shrestha (1981), Terashima (1984), Jha and Shrestha (1986), Edds (1986ab), Talwar and Jhingran (1991), Giri (1992), Subba (1995), Subba and Ghosh (1996), Bhagat (1998), Niroula and Subba (2004), Edds (2007), Shrestha (2008) and Shrestha (2013), deserve special mention. The authors have made several sincere painstaking attempts to survey the fishes 
of different regions of Nepal in different years and have reported their status. The present work targets to carry out a detailed survey on ichthyofaunal diversity of Morang district as there is scanty of detailed information on the fishes of entire district.

\section{Study area}

Morang district has spread over $1,855 \mathrm{~km}^{2}$ which comprises lower tropical (80.9\%), upper tropical $(11.55 \%)$, subtropical $(7.4 \%)$ and temperate $(0.2 \%)$. The lowest and highest altitudes of Morang district recorded are $60 \mathrm{~m}$ msl and 2410 $\mathrm{m}$ msl, respectively. As the district has occupied both Tarai and southern slope of Mahabharat Hills encompassing Churiya Hills, both warmwater and cold-water fishes are found in this belt. Most of the rivers of this district take their origin from the foot of the Mahabharat Hills and Churia Hills and make their courses towards south. The rivers, streams and other water bodies were selected and surveyed seasonally for the present survey of ichthyo-fauna of the entire district (Fig. 1). Besides, natural water sources mentioned above, man-made ponds, reservoirs, canals, ditches, pools were also included in the fish survey.

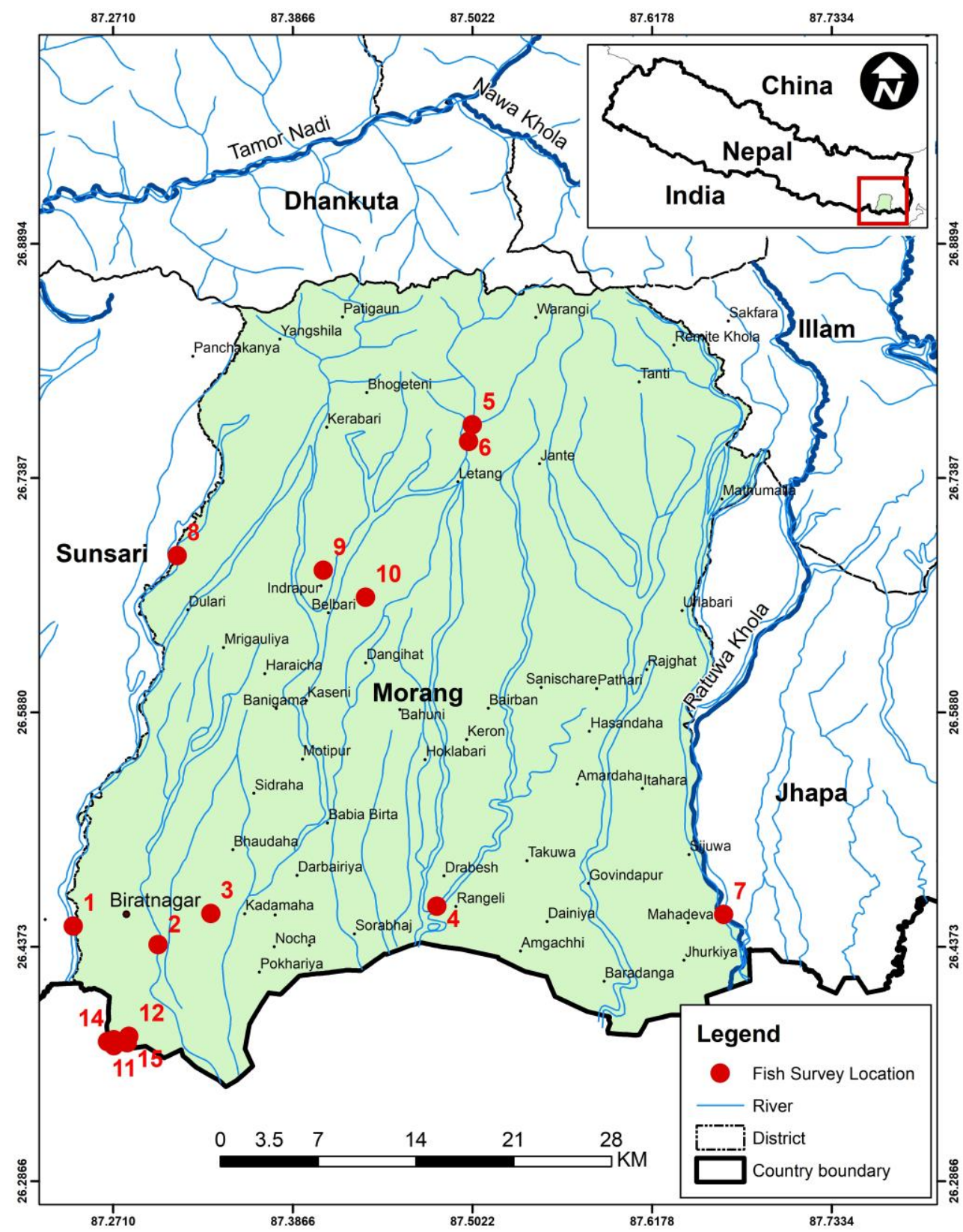

Figure 1. Study area map of Morang district showing fish survey locations. 1. Keshaliya Khola 2. Singia Khola 3. Lohandhra Khola 4. Bakraha Khola 5. Chisang Khola 6. Chisang Khola near Letang 7. Ratuwa Khola 8. Hashina Simsar 9. Bagh Jhoda Simsar 10. Betna Simsar 11. Khokraha Pokhari 12. Kichakbad Pokhari 13. Dharohar Pokhari 14. Diggi Pokhari 15. Bhaisiya Pokhari 


\section{Materials and methods}

Fishes were collected with the help of local fishermen using cast nets, scoop nets, hooks, Dhadiya and considering the necessity, diversion of rivers was also done at some places so as to collect small hill-stream fish species. The collected fishes were washed in clean water and photographed with a Sony digital camera, after removing water from their body surface with the help of towel and paper with a view to make identification of fishes easy. To make less confusion to identify fishes with the help of their body color, mainly adult fishes were photographed. Natural color of each and every fish sample was recorded in fresh condition. Fishes were preserved first in $40 \%$ formalin for eight to ten hours then in $8 \%$ formalin. The collected fishes were transported to ichthyological laboratory of Department of Zoology, Post Graduate Campus, Biratnagar, Nepal. Final identification and confirmation of fishes were performed following standard taxonomic books and literature on fishes. Morphometric measurement and meristic counts were done one after another. The data of both morphometric measurement and meristic counts were tallied with standard descriptions for confirmation. Collected and identified fishes have been kept with tags in the Department of Zoology, Post Graduate Campus Biratnagar.

\section{Results and discussion}

A total of 118 fish species belonging to 11 orders 26 families and 64 genera were recorded (Table 1, Fig. 2). The result of the present work was the outcome of more than 15 months regular field survey. Several fish species which have been reported from rivers of more or less same climatic regions of other parts of Nepal as well were found in the water resources of Morang district. The present study revealed that $51.3 \%$ of the total fish species recorded from Nepal inhabit the water bodies of Morang district.

Table 1. A list of fish species of Morang district.

\begin{tabular}{|c|c|c|c|}
\hline Order & Family & Species & CS \\
\hline Anguilliformes & Anguillidae & 1. Anguilla bengalensis (Gray) & $\mathrm{R}$ \\
\hline \multirow{2}{*}{ Clupeiformes } & Clupeidae & 2. Gudusia chapra (Hamilton- Buchanan) & $\mathrm{C}$ \\
\hline & & 3. G. variegata (Day) & $\mathrm{C}$ \\
\hline Clupeiformes & Engraulidae & 4. Setipinna phasa (Hamilton- Buchanan) & $\mathrm{C}$ \\
\hline Osteoglossiformes & Notopteridae & 5. Notopterus notopterus (Pallas) & $\mathrm{UC}$ \\
\hline \multirow[t]{26}{*}{ Cypriniformes } & Cyprinidae & 6. Catla catla (Hamilton- Buchanan) & $\mathrm{C}$ \\
\hline & & 7. Chagunius chagunio (Hamilton- Buchanan) & $\mathrm{C}$ \\
\hline & & 8. Cirrhinus mrigala (Hamilton- Buchanan) & $\mathrm{C}$ \\
\hline & & 9. C. reba (Hamilton- Buchanan) & $\mathrm{C}$ \\
\hline & & 10. Cyprinon semiplotus (McClelland) & $\mathrm{UC}$ \\
\hline & & 11. Schizothorax plagiostomus (Heckel)) & $\mathrm{C}$ \\
\hline & & 12. Labeo bata (Hamilton- Buchanan) & $\mathrm{UC}$ \\
\hline & & 13. L. boga (Hamilton- Buchanan) & $\mathrm{C}$ \\
\hline & & 14. L. caeruleus (Hamilton- Buchanan) & $\mathrm{UC}$ \\
\hline & & 15. L. calbasu (Hamilton- Buchanan) & $\mathrm{C}$ \\
\hline & & 16. L. dero (Hamilton- Buchanan) & $\mathrm{C}$ \\
\hline & & 17. L. dyocheilus (Hamilton- Buchanan) & $\mathrm{C}$ \\
\hline & & 18. L. fimbriatus (Hamilton- Buchanan) & UC \\
\hline & & 19. L. gonius (Hamilton- Buchanan) & $\mathrm{C}$ \\
\hline & & 20. L. pangusia (Hamilton- Buchanan) & $\mathrm{C}$ \\
\hline & & 21. L. rohita (Hamilton- Buchanan) & $\mathrm{UC}$ \\
\hline & & 22. Neolissochilus hexagonolepis (McClelland) & Rare \\
\hline & & 23. Puntius chola (Hamilton- Buchanan) & $\mathrm{C}$ \\
\hline & & 24. P. gonionotus (Bleeker) & $\mathrm{UC}$ \\
\hline & & 25. P. phutunio (Hamilton- Buchanan) & $\mathrm{UC}$ \\
\hline & & 26. P. sarana (Hamilton- Buchanan) & $\mathrm{UC}$ \\
\hline & & 27. P. sophore (Hamilton- Buchanan) & FC \\
\hline & & 28. P. terio (Hamilton- Buchanan) & $\mathrm{C}$ \\
\hline & & 29. P. ticto (Hamilton- Buchanan) & $\mathrm{C}$ \\
\hline & & 30. Tor putitora (Hamilton- Buchanan) & E \\
\hline & & 31. Chela laubuca (Hamilton- Buchanan) & $\mathrm{UC}$ \\
\hline
\end{tabular}




\begin{tabular}{|c|c|c|c|}
\hline & & 32. Salmostoma acinaces (Valenciennes) & $\mathrm{UC}$ \\
\hline & & 33. S. bacaila (Hamilton- Buchanan) & $\mathrm{UC}$ \\
\hline & & 34. S. phulo (Hamilton- Buchanan) & $\mathrm{UC}$ \\
\hline & & 35. Amblypharyngodon microlepis (Bleeker) & $\mathrm{FC}$ \\
\hline & & 36. A. mola (Hamilton- Buchanan) & $\mathrm{UC}$ \\
\hline & & 37. Aspidoparia jaya (Hamilton- Buchanan) & $\mathrm{C}$ \\
\hline & & 38. A. morar (Hamilton- Buchanan) & $\mathrm{C}$ \\
\hline & & 39. Barilius barna (Hamilton- Buchanan) & $\mathrm{C}$ \\
\hline & & 40. B. bendelisis (Hamilton- Buchanan) & FC \\
\hline & & 41. B. shacra (Hamilton- Buchanan) & $\mathrm{UC}$ \\
\hline & & 42. B. vagra (Hamilton- Buchanan) & $\mathrm{UC}$ \\
\hline & & 43. Brachydanio rerio (Hamilton- Buchanan) & $\mathrm{C}$ \\
\hline & & 44. Danio devario (Hamilton- Buchanan) & $\mathrm{UC}$ \\
\hline & & 45. Esomus danricus (Hamilton- Buchanan) & $\mathrm{C}$ \\
\hline & & 46. Raiamas bola (Hamilton- Buchanan) & $\mathrm{C}$ \\
\hline & & 47. R. guttatus (Day) & $\mathrm{UC}$ \\
\hline & & 48. Crossocheilus latius latius (Hamilton- Buchanan) & $\mathrm{C}$ \\
\hline & & 49. Garra annandalei (Hora) & $\mathrm{FC}$ \\
\hline & & 50. G. gotyla gotyla (Gray) & $\mathrm{FC}$ \\
\hline & & 51. G. mullya (Sykes) & $\mathrm{C}$ \\
\hline & & 52. G. rupecula (McClelland) & $\mathrm{UC}$ \\
\hline & Psilorhynchidae & 53. Psilorhynchus balitora (Hamilton- Buchanan) & $\mathrm{UC}$ \\
\hline & & 54. P. pseudecheneis (Menon \& Datta) & $\mathrm{UC}$ \\
\hline & & 55. P. sucatio (Hamilton- Buchanan) & $\mathrm{UC}$ \\
\hline & Cobitidae & 56. Acanthocobitis botia (Hamilton- Buchanan) & $\mathrm{FC}$ \\
\hline & & 57. Nemacheilus corica (Hamilton- Buchanan) & $\mathrm{C}$ \\
\hline & & 58. Schistura himachalensis (Menon) & $\mathrm{C}$ \\
\hline & & 59. S. horai (Menon) & $\mathrm{C}$ \\
\hline & & 60. S. rupecula (Mc Clelland) & $\mathrm{C}$ \\
\hline & & 61. S. savona (Hamilton-Buchanan) & $\mathrm{C}$ \\
\hline & & 62. Lepidocephalus guntea (Hamilton- Buchanan) & $\mathrm{FC}$ \\
\hline & & 63. Somileptes gangota (Hamilton- Buchanan) & $\mathrm{C}$ \\
\hline & & 64. Botia lohachata (Chaudhuri) & $\mathrm{C}$ \\
\hline Siluriformes & Bagridae & 65. Aorichthys aor (Hamilton- Buchanan) & $\mathrm{C}$ \\
\hline & & 66. Mystus bleekeri (Day) & $\mathrm{C}$ \\
\hline & & 67. M. cavasius (Hamilton- Buchanan) & $\mathrm{C}$ \\
\hline & & 68. M. tengra (Hamilton- Buchanan) & $\mathrm{C}$ \\
\hline & & 69. M. vittatus (Bloch) & $\mathrm{C}$ \\
\hline & Siluridae & 70. Ompok bimaculatus (Bloch) & $\mathrm{C}$ \\
\hline & & 71. O. pabda (Hamilton- Buchanan) & $\mathrm{UC}$ \\
\hline & & 72. Wallago attu (Schneider) & $\mathrm{C}$ \\
\hline & Schilbeidae & 73. Ailia coila (Hamilton- Buchanan) & $\mathrm{UC}$ \\
\hline & & 74. Clupisoma garua (Hamilton- Buchanan) & $\mathrm{C}$ \\
\hline & & 75. C. montana (Hora) & $\mathrm{UC}$ \\
\hline & & 76. Eutropiichthys vacha (Hamilton- Buchanan) & $\mathrm{C}$ \\
\hline & Olyridae & 77. Olyra longicaudata (McCleland) & $\mathrm{T}$ \\
\hline & Amblycipitidae & 78. Amblyceps mangois (Hamilton- Buchanan) & $\mathrm{C}$ \\
\hline & Clariidae & 79. Bagarius bagarius (Linnaeus) & UC \\
\hline & & 80. Gagata cenia (Hamilton- Buchanan) & $\mathrm{C}$ \\
\hline & & 81. Glyptothorax alakanandi (Tilak) & $\mathrm{C}$ \\
\hline & & 82. G. annandalei (Hora) & $\mathrm{UC}$ \\
\hline & & 83. G. cavia (Hamilton- Buchanan) & $\mathrm{C}$ \\
\hline & & 84. G. pectinopterus (McClelland) & $\mathrm{C}$ \\
\hline & & 85. G. telchitta (Hamilton- Buchanan) & $\mathrm{C}$ \\
\hline & & 86. G. trilineatus (Blyth) & $\mathrm{UC}$ \\
\hline
\end{tabular}




\begin{tabular}{|c|c|c|c|}
\hline & & 87. Pseudecheneis sulcatus (McClelland) & $\mathrm{C}$ \\
\hline & & 88. Hara hara (Hamilton- Buchanan) & $\mathrm{C}$ \\
\hline & & 89. Nangra assamensis (Sen and Biswas) & $\mathrm{C}$ \\
\hline & & 90. N. viridescens (Hamilton- Buchanan) & $\mathrm{C}$ \\
\hline & & 91. Sisor rhabdophor(Hamilton- Buchanan) & $\mathrm{C}$ \\
\hline & & 92. S. rheophilus $(\mathrm{Ng})$ & $\mathrm{UC}$ \\
\hline & & 93. Clarias batrachus (Linnaeus) & $\mathrm{C}$ \\
\hline & Heteropneustidae & 94. Heteropnenustes fossillis (Bloch) & $\mathrm{C}$ \\
\hline & Chacidae & 95. Chaca chaca (Hamilton- Buchanan) & $\mathrm{UC}$ \\
\hline Beloniformes & Belonidae & 96. Xenentodon cancila (Hamilton- Buchanan) & $\mathrm{C}$ \\
\hline Cyprinodontiformes & Aplocheilidae & 97. Aplocheilus panchax (Hamilton- Buchanan) & $\mathrm{UC}$ \\
\hline Synbranchiformes & Synbranchidae & 98. Monopterus cuchia (Hamilton- Buchanan) & UC \\
\hline Perciformes & Mastacembelidae & 99. Macrognathus aral (Bloch \&Schneider) & $\mathrm{C}$ \\
\hline & & 100. M. spancalus (Hamilton Buchanan) & UC \\
\hline & & 101. M. armatus (Lacepede) & $\mathrm{C}$ \\
\hline & Ambassidae & 102. Chanda nama (Hamilton- Buchanan) & $\mathrm{C}$ \\
\hline & & 103. Pseudombassis baculis (Hamilton- Buchanan) & $\mathrm{C}$ \\
\hline & & 104. P. lala (Hamilton- Buchanan) & $\mathrm{UC}$ \\
\hline & & 105. P. ranga (Hamilton- Buchanan) & $\mathrm{C}$ \\
\hline & Nandidae & 106. Nandus nandus (Hamilton) & $\mathrm{UC}$ \\
\hline & Gobiidae & 107. Badis badis (Hamilton- Buchanan) & $\mathrm{C}$ \\
\hline & & 108. Glossogobius giuris (Hamilton- Buchanan) & $\mathrm{C}$ \\
\hline & Anabantidae & 108. Anabas cobojius (Hamilton- Buchanan) & $\mathrm{UC}$ \\
\hline & & 106. A. testudineus (Bloch) & $\mathrm{C}$ \\
\hline & Osphronemidae & 107. Colisa fasciatus (Bloch and Schneider) & $\mathrm{C}$ \\
\hline & & 108. C. lalius (Hamilton- Buchanan) & $\mathrm{C}$ \\
\hline & & 109. Polyacanthus sota (Hamilton- Buchanan) & $\mathrm{UC}$ \\
\hline & Channidae & 114. Channa marulius ( Hamilton-Buchanan) & $\mathrm{UC}$ \\
\hline & & 115. C. orientalis (Bloch and Schneider) & FC \\
\hline & & 116. C. punctatus (Bloch) & $\mathrm{C}$ \\
\hline & & 117. C. striatus (Bloch) & FC \\
\hline Tetraodontiformes & Tetraodontidae & 118. Tetraodon cutcutia (Hamilton- Buchanan) & $\mathrm{C}$ \\
\hline
\end{tabular}

The important outcome of the present work was listing of hill-stream fishes viz., Schizothorax plagiostomus, Schistura savona and Olyra longicaudata which had not been described earlier (Bhagat, 1998) from this district. In addition to these fish species, presence of Neolissochilus hexagonolepis in Chisang river up to two decades back was supported strongly by local fishermen but unfortunately, the total elimination of the fish from Chisang river at present is attributed to merciless anthropogenic activities such as poisoning, electro fishing and over fishing. Olyra longicaudata was first reported in Nepal (Subba, 1995) but not from the present location of Morang district but from the same Churia range of Udayapur district. This species has been considered as threatened species (Lakra et al., 2010) and one of the most endangered endemic catfish inhabiting mountain streams of eastern Himalaya (Kachari et al.,
2014). As the occurrence of this fish species is restricted to limited geographical regions from wherever it has been reported, so it is in dire need of conservation. Shrestha (1990) reported rare fishes of Himalayan waters of Nepal.

Colisa fasciatus was the most common and successful breeder in rainy season in pools, ditches, canals, especially in shallow waters in Morang district but the population of this fish has declined remarkably in the study areas, probably due to the impact of climate change. Similarly, Clarias batrachus, Brachydenio rerio, Anabas cobojius, Polycanthus sota, Monopterus cuchia, Ompok pabda, O. bimaculatus, Psilorhynchus balitora, though they are available but were hardly captured during survey of the study area. Their population seems to have undergone a significant decline which seems likely to continue. Cyprinon semiplotus was recorded 
only in Keshaliya Khola. Among Channa species, $C$. orientalis and $C$. striatus were fairly common; rest species of Channa were uncommon. Chaca chaca and Nandus nandus were hard to collect. Their population has decreased alarmingly due to the loss of their suitable habitats and increased pollution. Sisor rheophilus, which has been reported from western rivers of Nepal, was also recorded in Keshaliya river.

Rajbanshi (2012) reported 230 native fish species belonging to 11 orders, 34 families and 104 genera from Nepal. Shrestha (2013) made a report of 228 indigenous fishes which belong to 11 orders, 32 families, 24 sub-families, and 99 genera including 15 endemic species. Earlier, Shrestha (2008) described a total of 232 fish species belonging to 114 genera under 37 families and 11 orders. Out of 232 species 217 are native to different aquatic systems and remaining 15 species are exotic. In this paper, only native species have been listed.

Edds (2007) reported Glyptothorax garhwali, Psilorhynchus gracilis, Nangra assamensis, and Sisor rheophilus from the Gadaki/Narayani river. Nangra assamensis, and Sisor rheophilus were reported to occur in the lower most reaches of the Narayani river. Though Sisor rhabdophorus was of rare occurrence in upper reaches of the Narayani river in Chitwan, it was uncommonly seen down from the Gandak barrage. This species was commonly appeared in Keshaliya river. Shrestha (2008) has made an account of both these species from the Gadaki/Narayani rivers. Also, $\mathrm{Ng}$ (2003) made a report on the rare occurrence of $S$. rheophilus from the upper stretches of the Narayani river. Further, 4 and 3 species of Pseudecheneis were accounted by Shrestha (2008). The single species of Pseudecheneis sulcatus was obtained in the present study.

Because of rich in water resources, Morang district is considered as a suitable place for fish culture. Both indigenous and exotic fish species thrive well in the aquatic habitats of this district. 8 exotic fish species viz., Ctenopharyngodon idella, Cyprinus carpio var. specularis, Cyprinus carpio var. communis, Hypophthalmichthys molitrix and Aristichthys nobilis belonging to the family Cyprinidae and Oreochromis niloticus, Clarias gariepinus and Pangasius hypophthalmus of the families Cichlidae, Clariidae and
Pangasiidae, respectively have been cultured in Morang district. With an addition of the exotic fishes to the present checklist, the total number of fishes inhabiting the water bodies of the district comes to be 126 but in the present report only indigenous fish species have been included. Most of the fish species were procured from Keshaliya and Lohandra rivers which are important for capture fisheries. As marshy lands, swamps, ditches and streams have almost turned into dry land due to years erratic monsoon and increased global atmospheric temperature caused by climate change, the most common fish species inhabit aforesaid habitats were found uncommon. However, some of the fish species which could become able to tolerate the globally raised temperature and water pollution were found still maintaining their population as it was earlier. To confirm the status of fish species, a record of fish species observed in regular surveys of local fish markets and direct interviews with local fishers and villagers from time to time at different places was maintained. The fifteen months data of fish species obtained from the regular observation and collection, in the whole Morang district depicted the results of present climatic condition and anthropogenic impacts on fish species (Table 1).

\section{Acknowledgements}

We are very thankful to District Agriculture Development Office, Morang for the financial support to carry out the survey. We are grateful to Junior Technician (JT) Ms. Parbati Limbu for her sincere assistance in official work during the project period. We would like to thank $\mathrm{Mr}$. Jageswar Sohani and his nephew (Fishermen) who helped us most honestly in the collection of fishes. We also thank Mr. Bishnu Singh Thakuri for his support in the preparation of a map. Finally, we would like to acknowledge with special thanks to all our well-wishers.

\section{References}

Bhagat, R.P. 1998. Fishes from Morang district of Eastern Nepal. J.Nat.Hist.Mus. 17(1-4):31-38.

Day, F. 1869. The fauna of British India, including Ceylon and Burma fishes. Vol. I and II, xvii 538p. William Division, London.

Edds, D.R. 1986a. The fishes of Royal Chitwan National Park. J. Nat. Hist.Mus. 10(1-4):1-12.

Edds, D.R. 1986b. Fishes of the Kali Gandaki/ Narayani River, Nepal. J. Nat. Hist. Mus. 10(1-4): 13-22. 
Subba, Pokharel and Pandey / Our Nature (2017), 15(1-2): 55-67

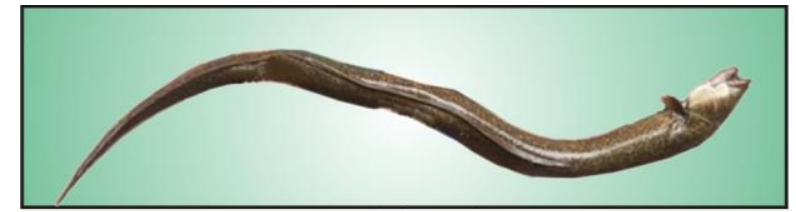

1. Anguilla bengalensis

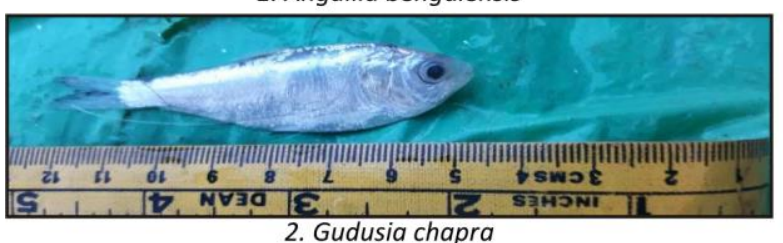

2. Gudusia chapra

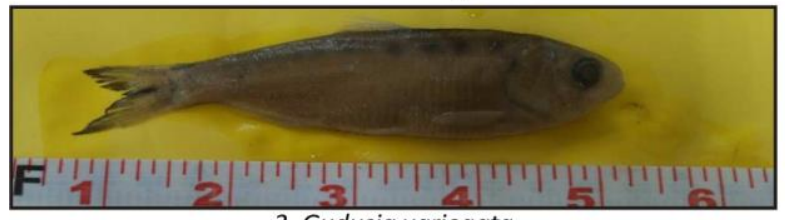

3. Gudusia variegata

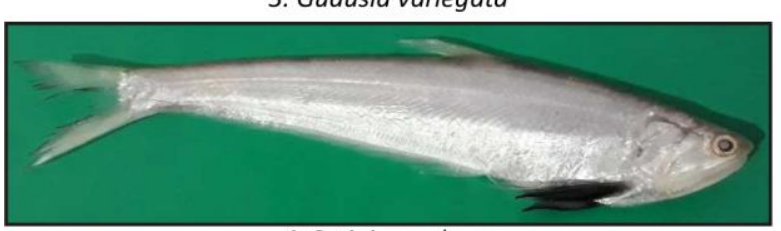

4. Setipinna phasa

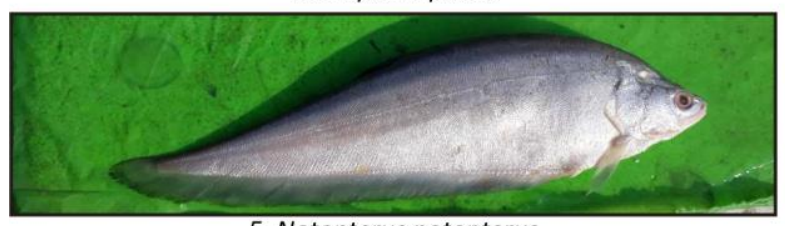

5. Notopterus notopterus

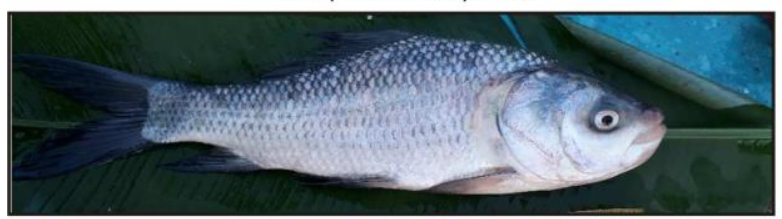

6. Catla catla

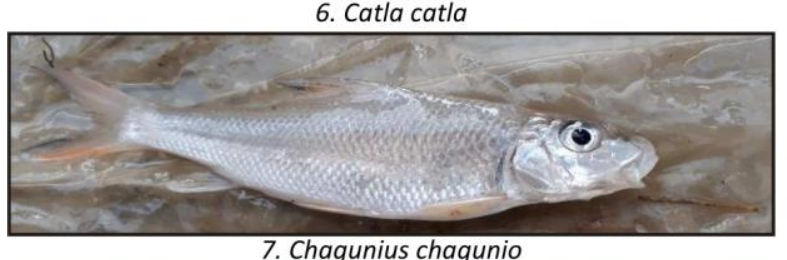

7. Chagunius chagunio

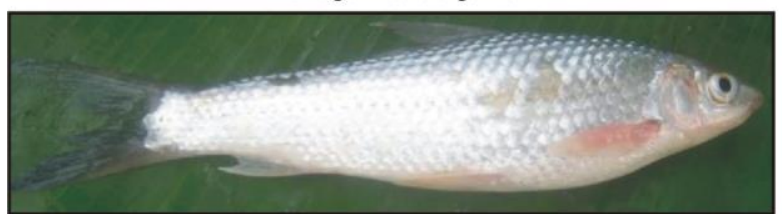

8. Cirrhinus mrigala

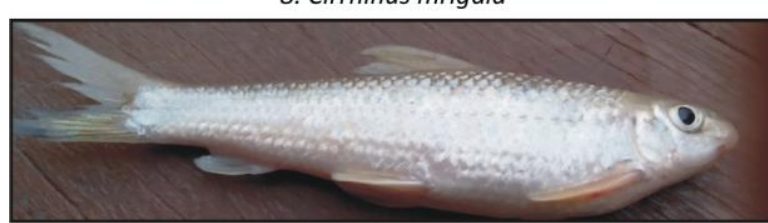

9. Cirrhinus reba

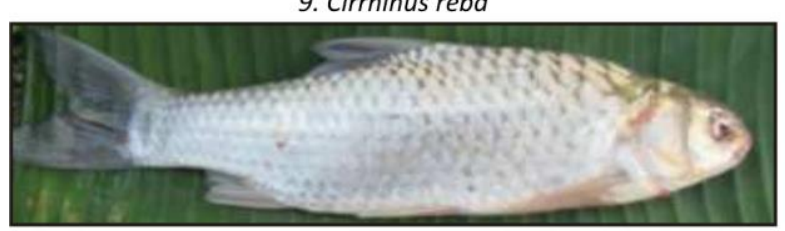

10. Cyprinon semiplotus

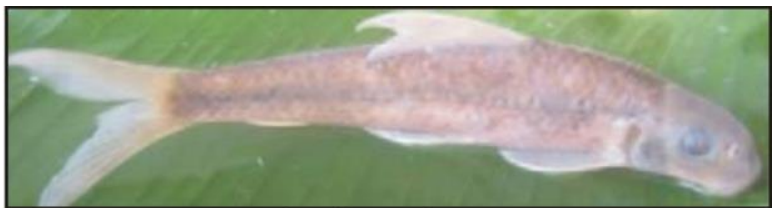

11. Schizothorax plagiostomus

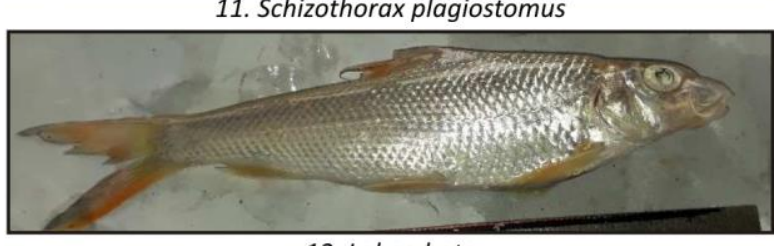

12. Labeo bata

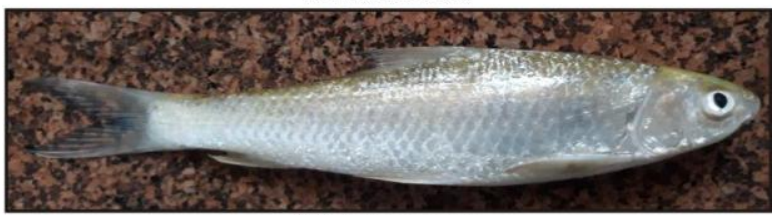

13. Labeo boga

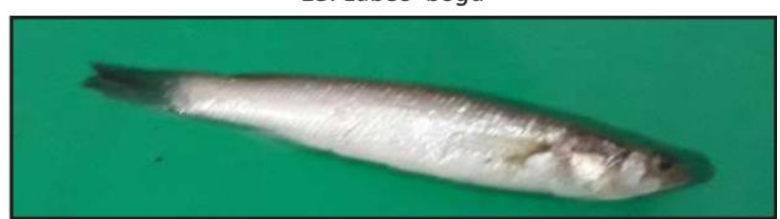

14. Labeo caeruleus

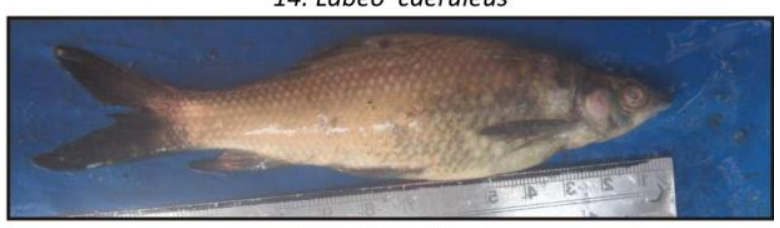

15. Labeo calbasu

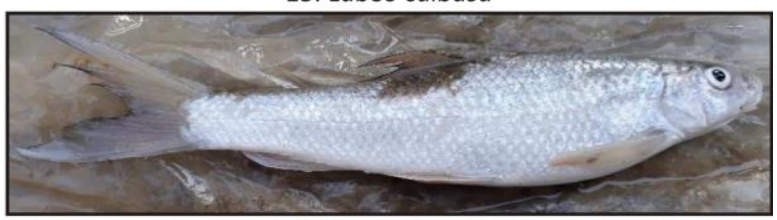

16. Labe dero

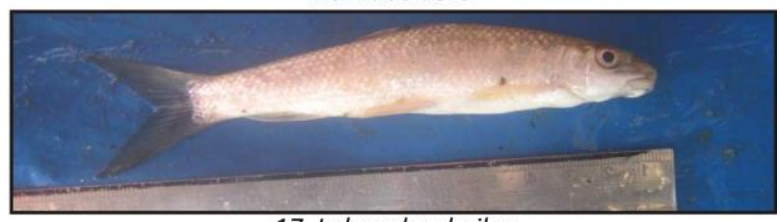

17. Labeo dyocheilus

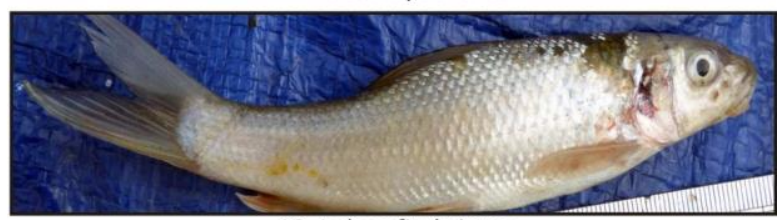

18. Labeo fimbriatus

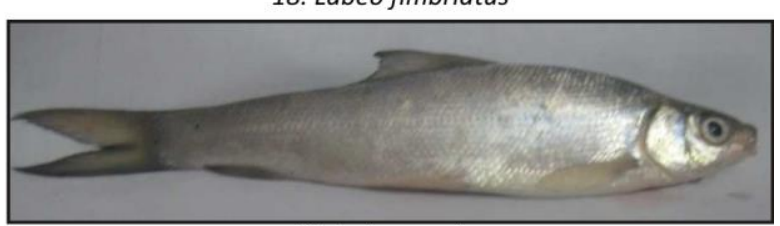

19. Labeo gonius

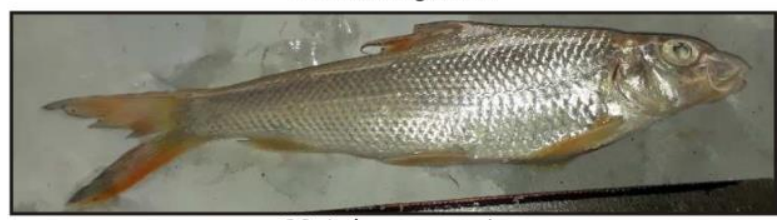

20. Labeo pangusia 
Subba, Pokharel and Pandey / Our Nature (2017), 15(1-2): 55-67

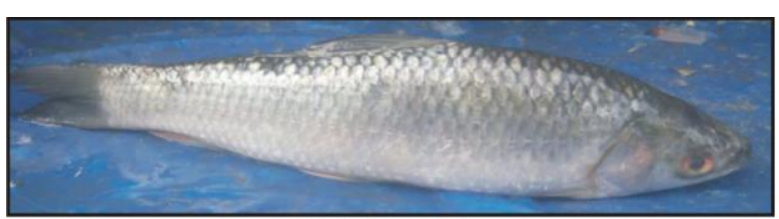

21. Labeo rohita

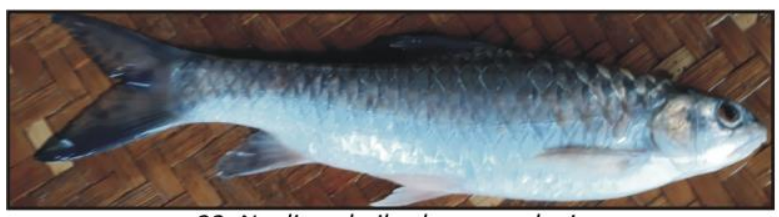

22. Neolissocheilus hexagonolepis

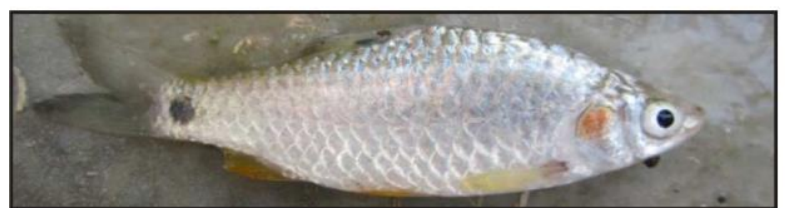

23. Puntius Chola

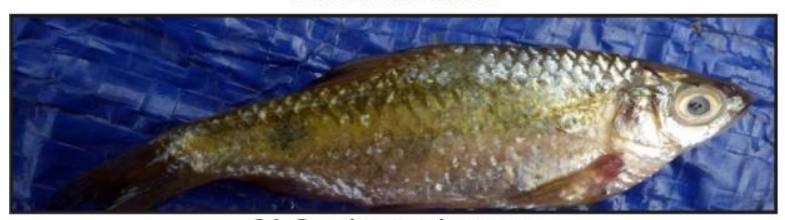

24. Puntius gonionotous

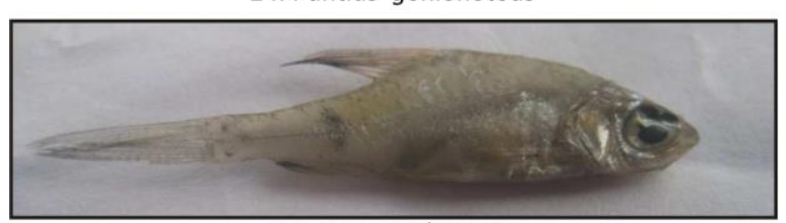

25. Puntius phutunio

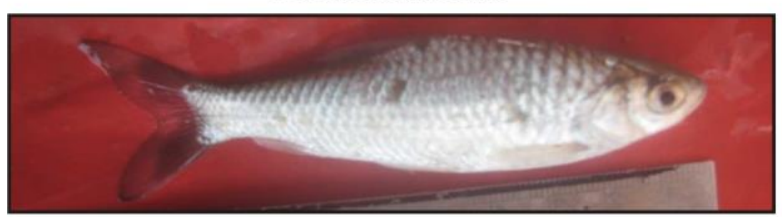

26. Puntius sarana sarana

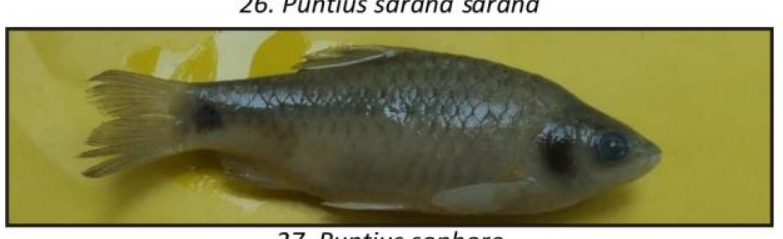

27. Puntius sophore

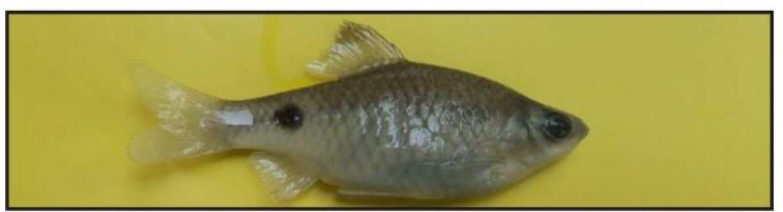

28. Puntius terio

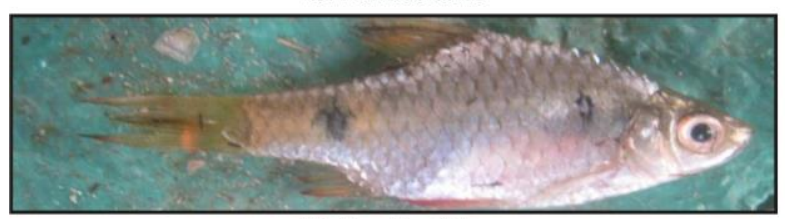

29. Puntius ticto

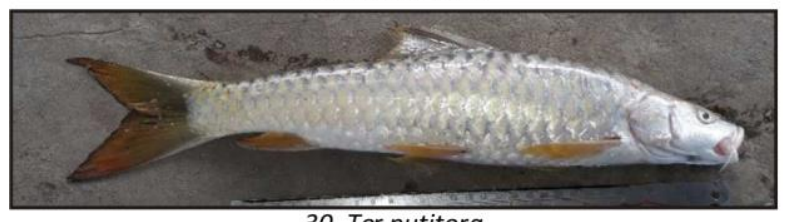

30. Tor putitora

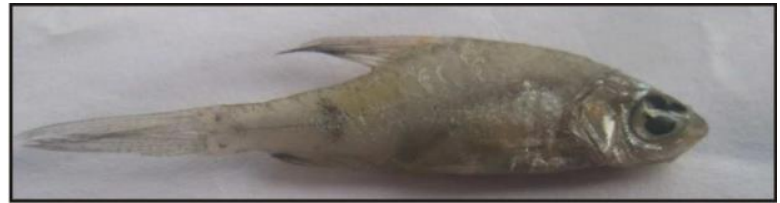

31. Chela labuca

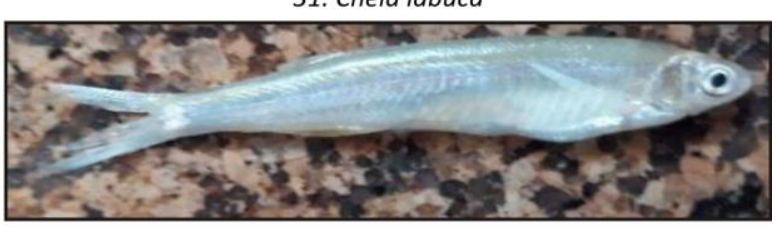

32. Salmostoma acinaces

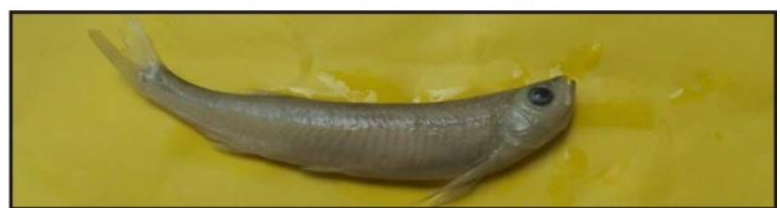

33. Salmostoma bacaila

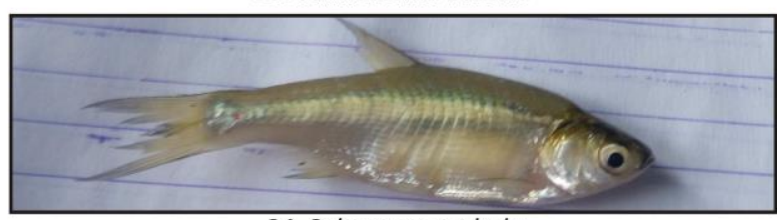

34. Salmostoma phulo

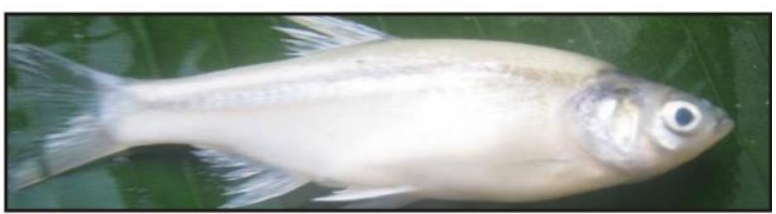

35. Amblyphryngodon microlepis

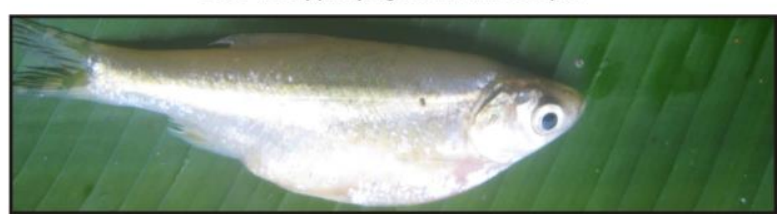

36. Amblypharyngodon mola

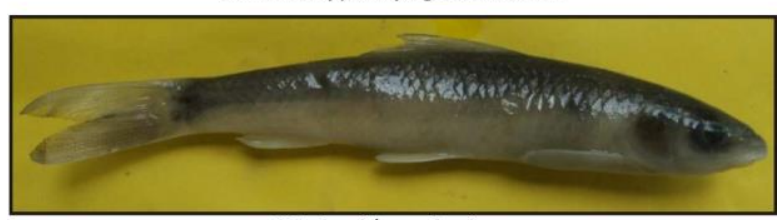

37. Aspidoparia jaya

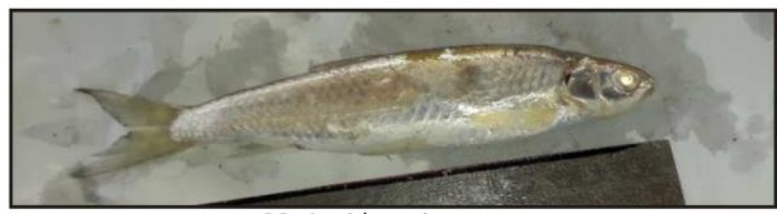

38. Aspidoparia morar

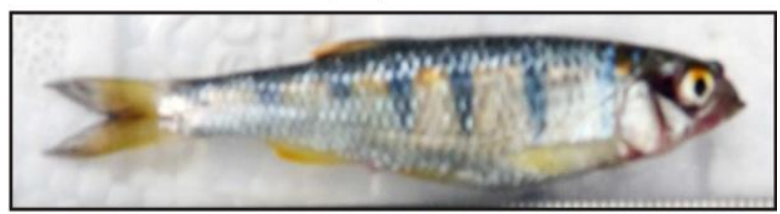

39. Barilius barna

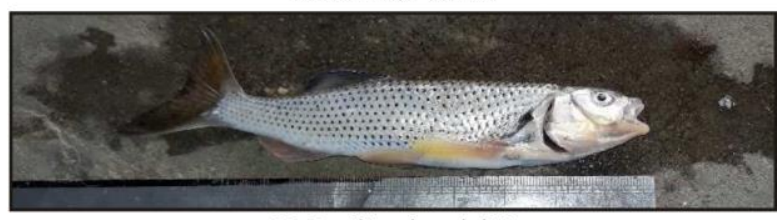

40. Barilius bendelisis 
Subba, Pokharel and Pandey / Our Nature (2017), 15(1-2): 55-67

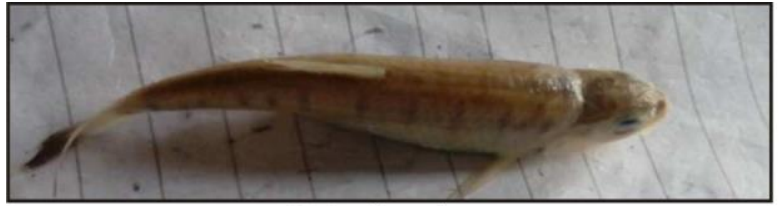

41. Barilius shacra

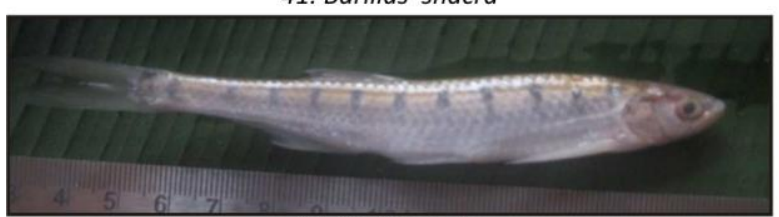

42. Barilus vagra

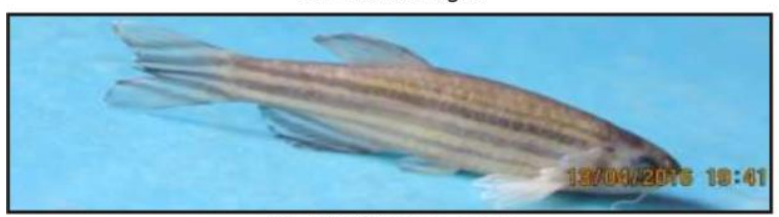

43. Brachydano rerio

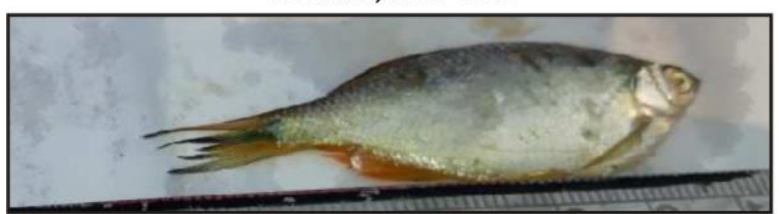

44. Danio devario

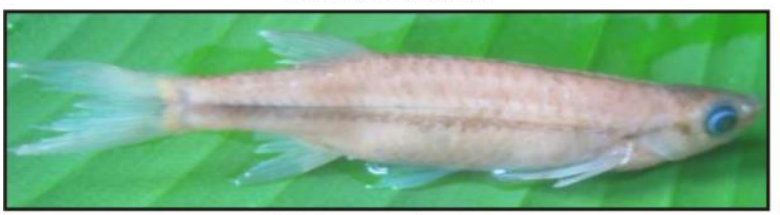

45. Esomus danricus

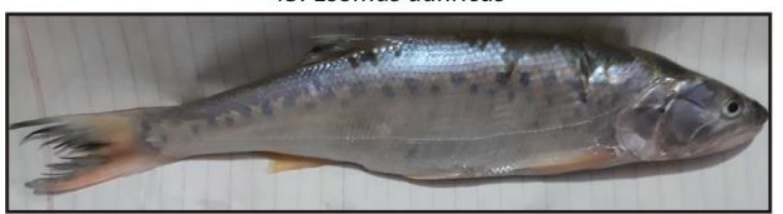

46. Raiamas bola

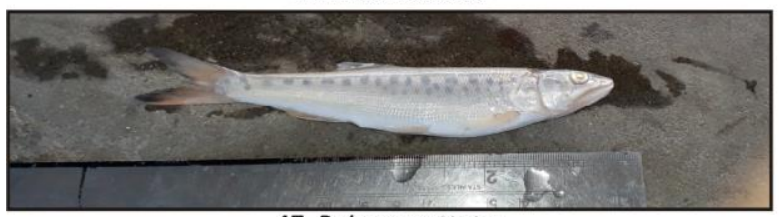

47. Raimas guttatus

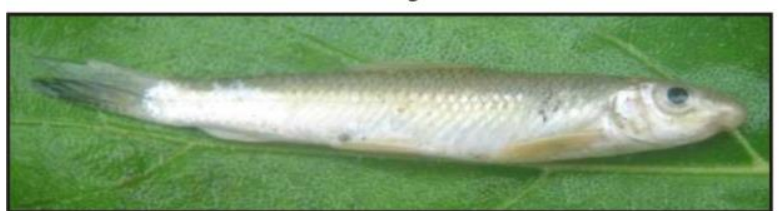

48. Crossocheilus latius

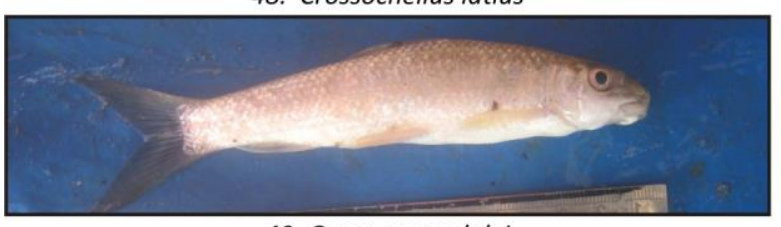

49. Garra annandalei

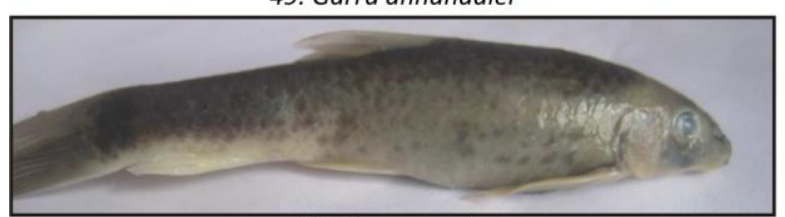

50. Garra gotyla

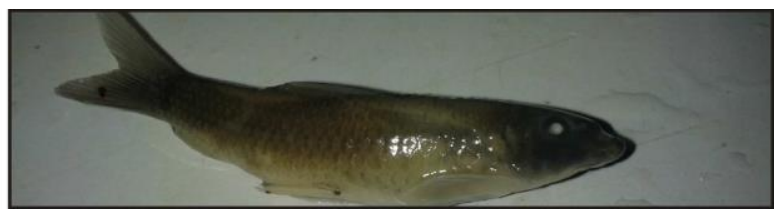

51. Garra mullya

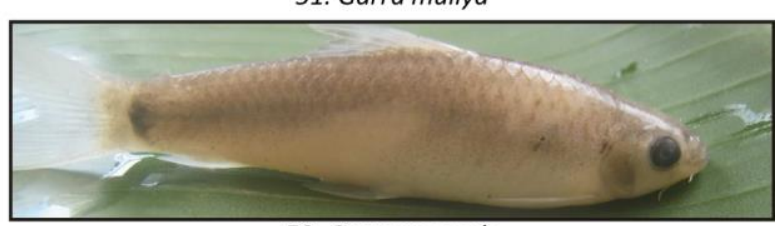

52. Garra rupecula

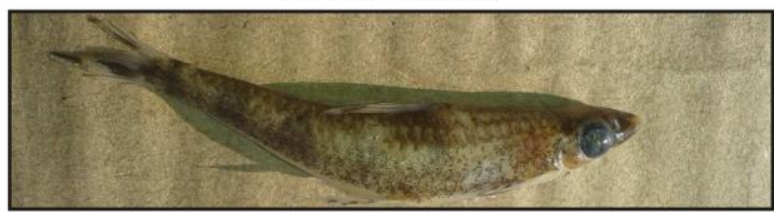

53. Psilorhynchus balitora

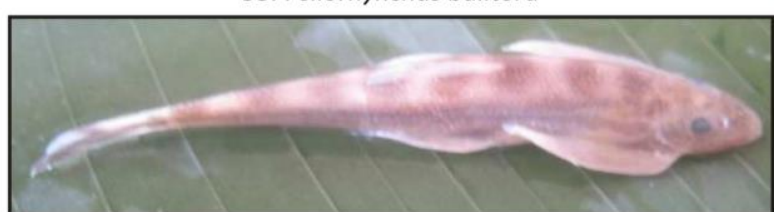

54. Psilorhynchus pseudecheneis

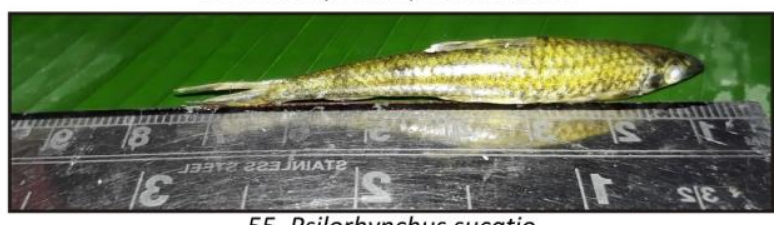

55. Psilorhynchus sucatio

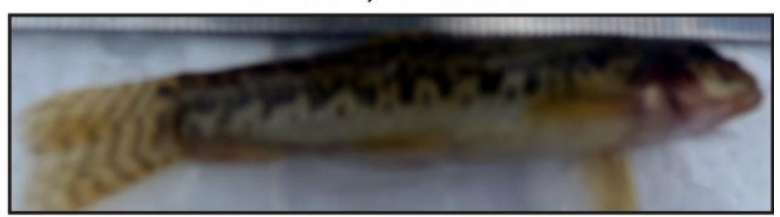

56. Acanthocobotis botia

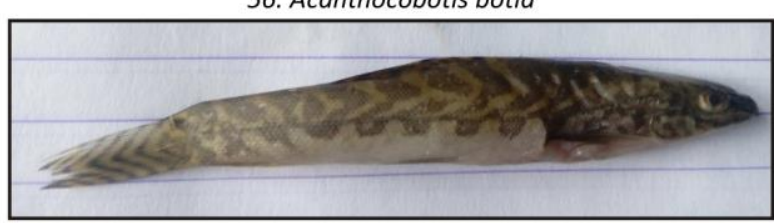

57. Nemacheilus corica

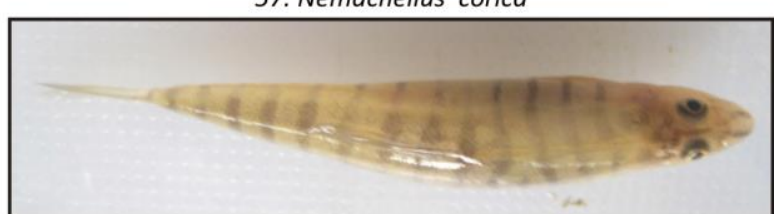

58. Schistura himachalensis

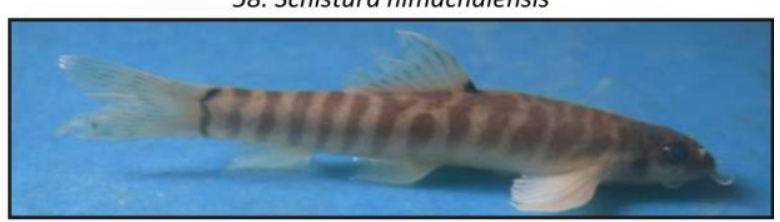

59. Schistura horai

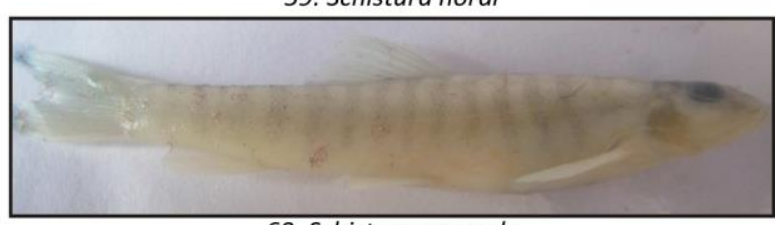

60. Schistura rupecula 
Subba, Pokharel and Pandey / Our Nature (2017), 15(1-2): 55-67

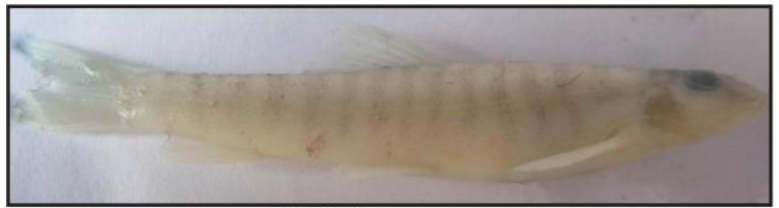

61. Schistura sovana

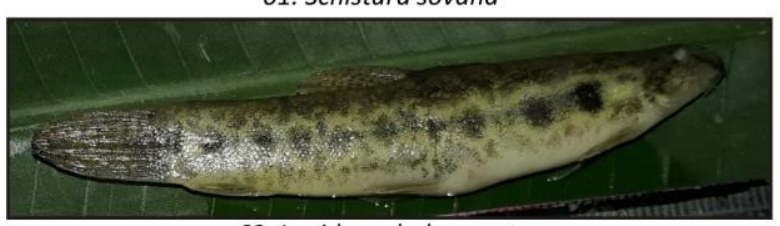

62. Lepidocephalus guntea

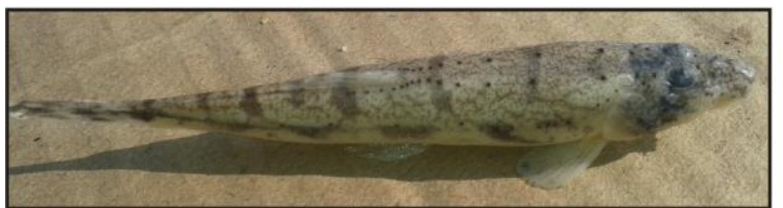

63. Somileptes gongota

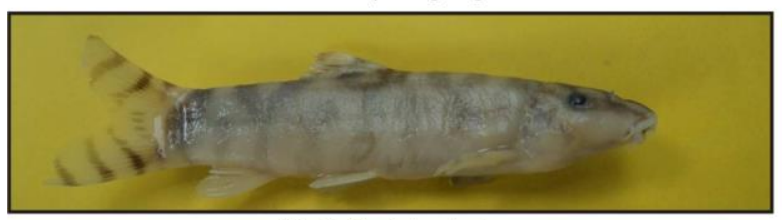

64. Botia lohachata

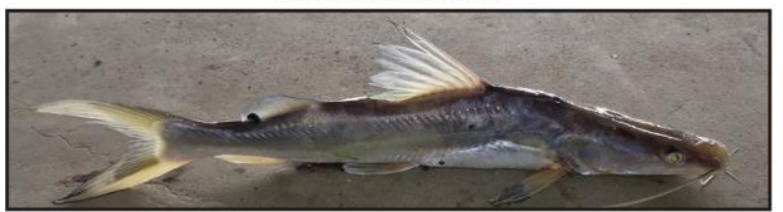

65. Aorichthys aor

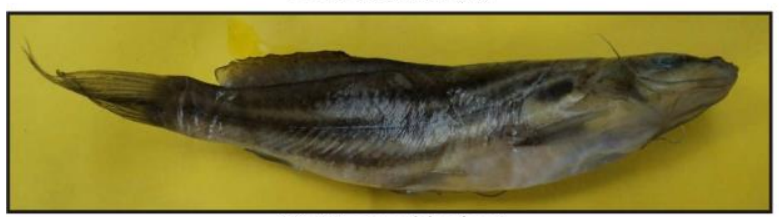

66. Mystus bleekeri

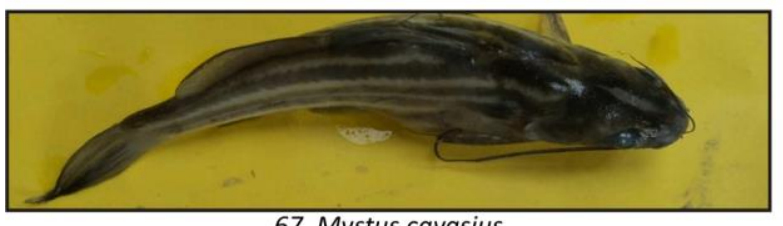

67. Mystus cavasius

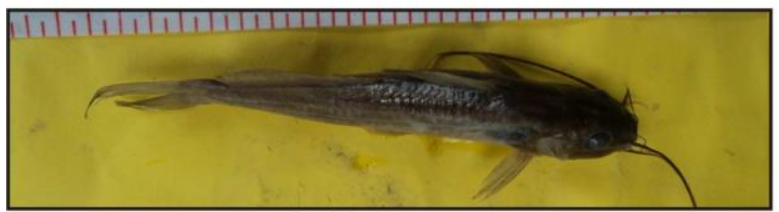

68. Mystus tengra

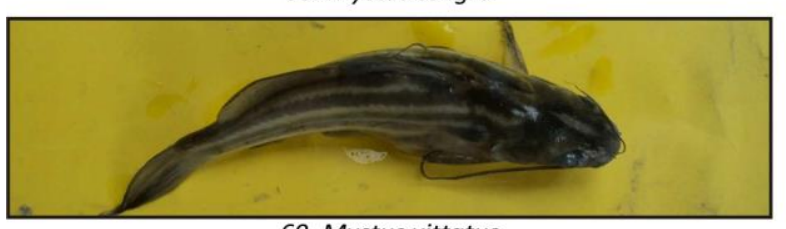

69. Mystus vittatus

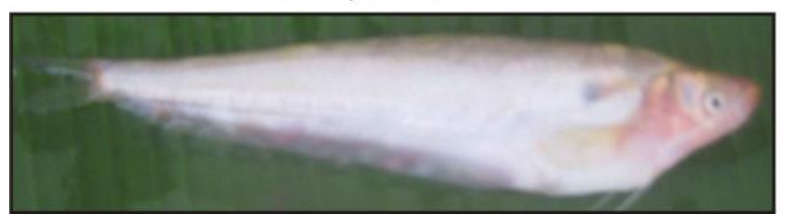

70. Ompok bimaculatus

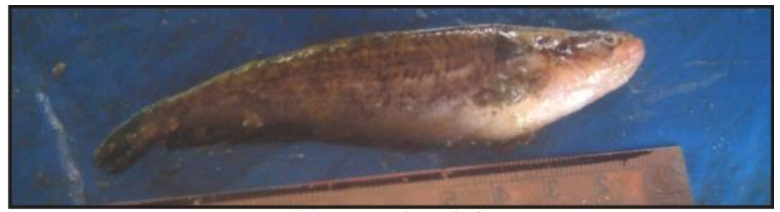

71. Ompok pabda

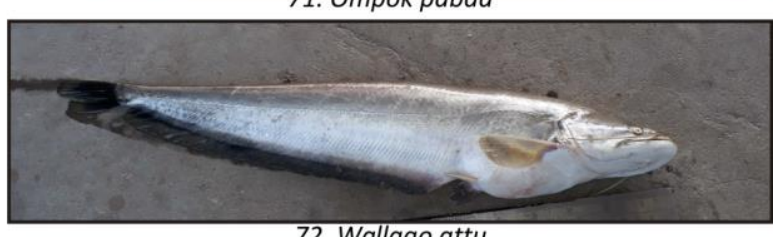

72. Wallago attu

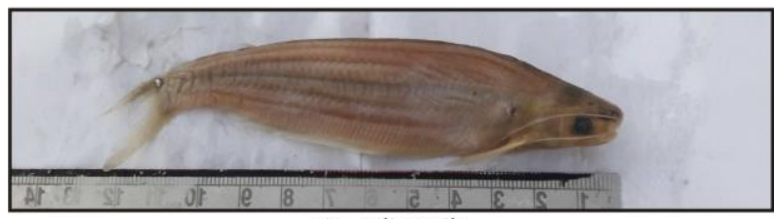

73. Ailia coila

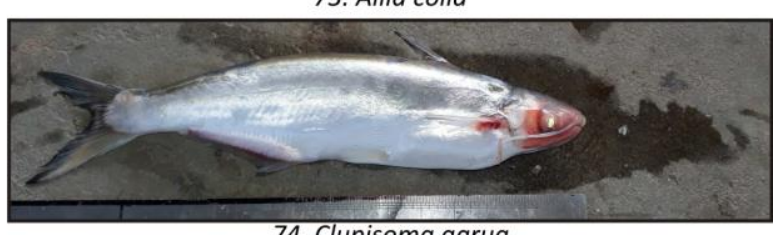

74. Clupisoma garua

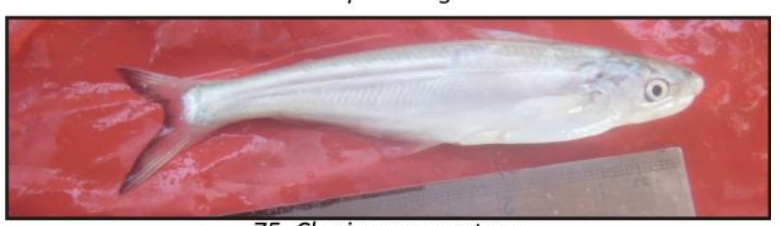

75. Clupisoma montana

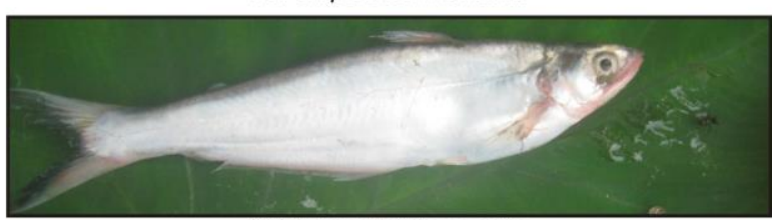

76. Eutropiichthys vacha

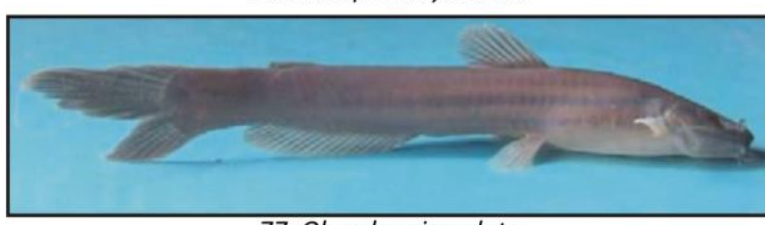

77. Olyra longicaudata

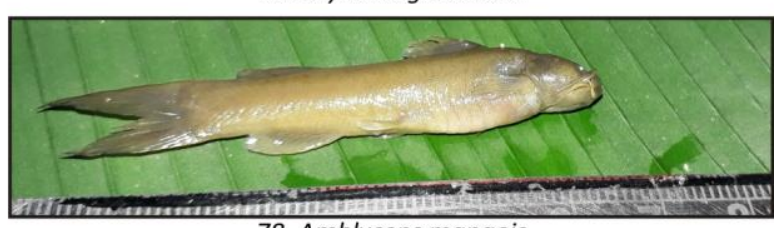

78. Amblyceps mangois

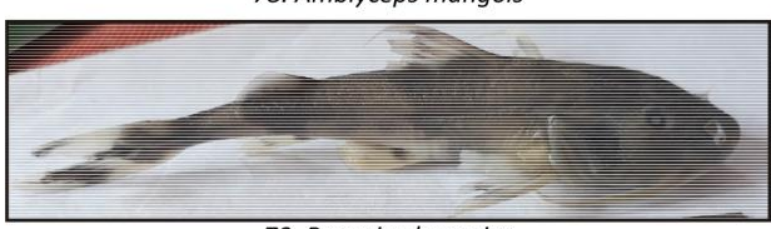

79. Bagarius bagarius

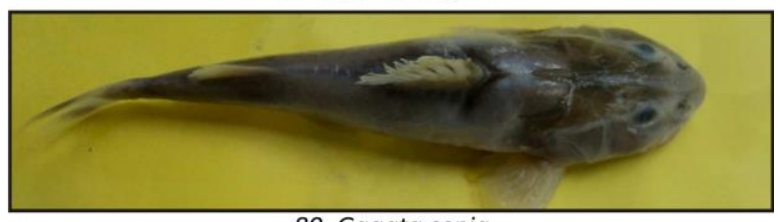

80. Gagata cenia 
Subba, Pokharel and Pandey / Our Nature (2017), 15(1-2): 55-67

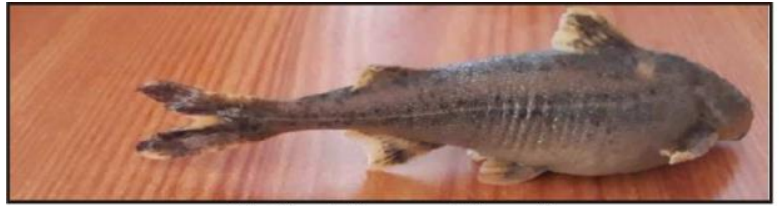

81. Glyptothorax alaknandi

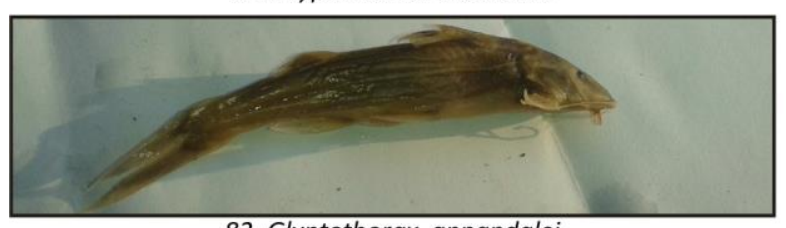

82. Glyptothorax annandalei

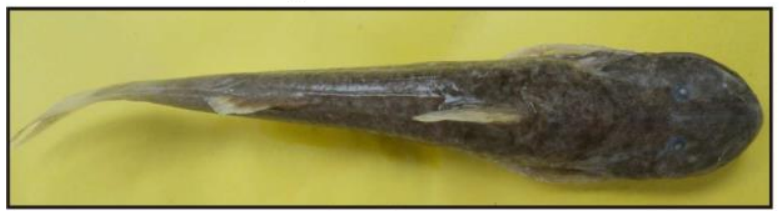

83. Glyptothorax cavia

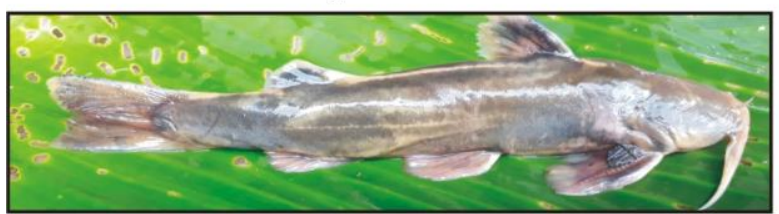

84. Glyptothorax pectinopterus

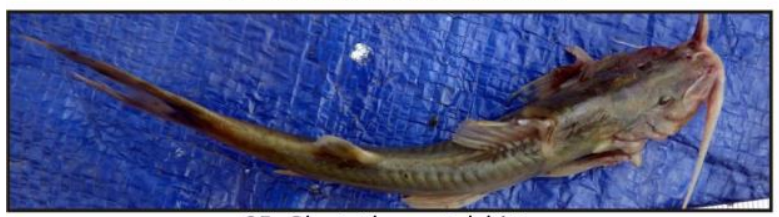

85. Glyptothorax telchitta

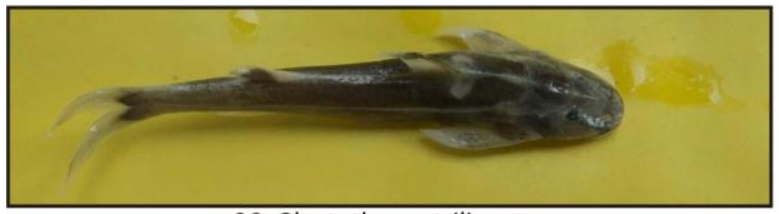

86. Glyptothorax trilineatus

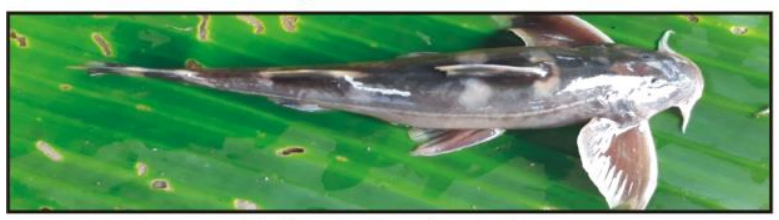

87. Pseudecheneis sulcatas

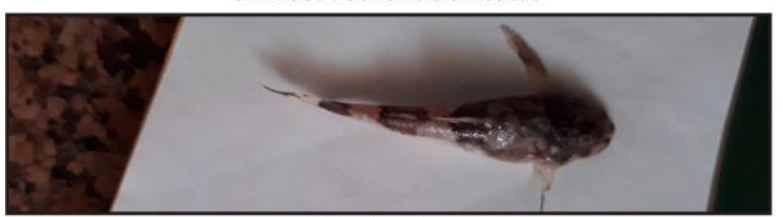

88. Hara hara

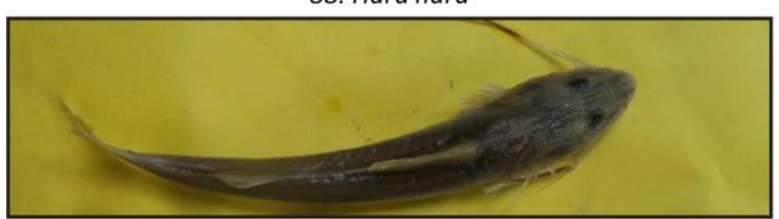

89. Nangra assamensis

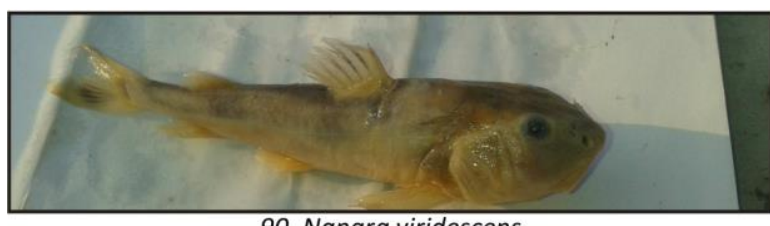

90. Nangra viridescens

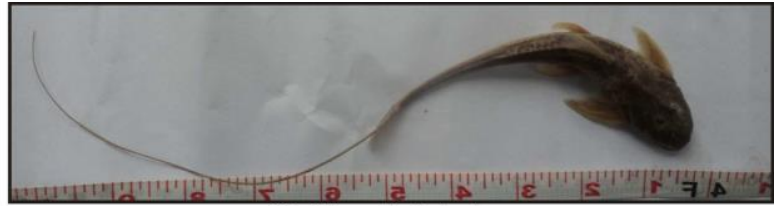

91. Sisor rhabdophor

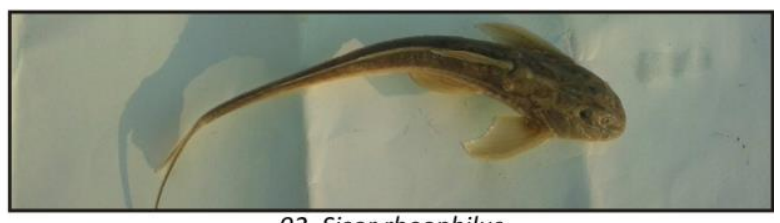

92. Sisor rheophilus

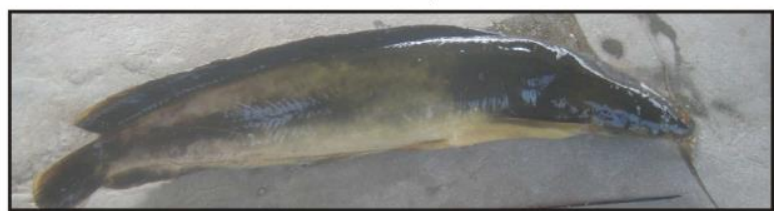

93. Clarias batrachus

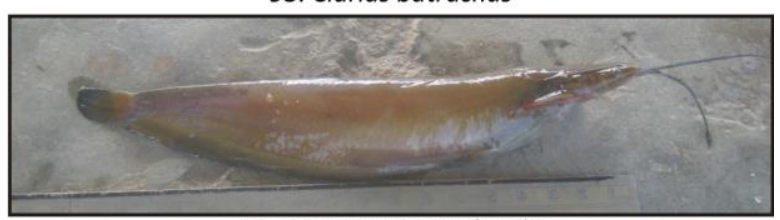

94. Heteropneustes fossilis

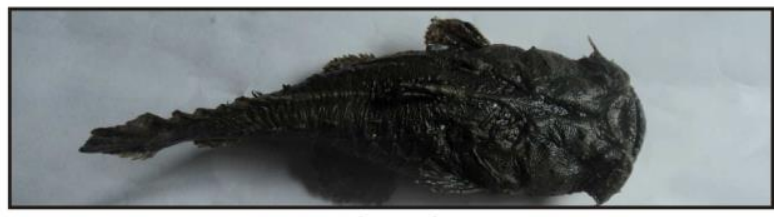

95. Chaca chaca

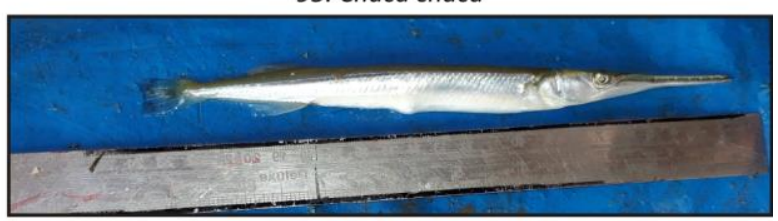

96. Xenentoden cancila

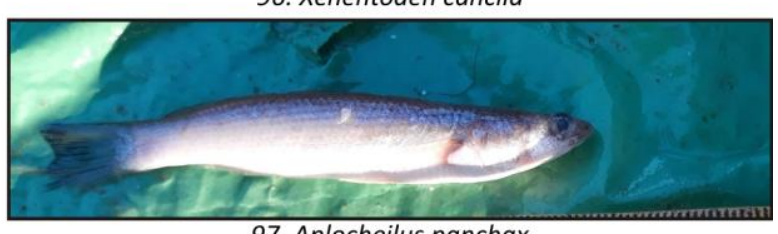

97. Aplocheilus panchax

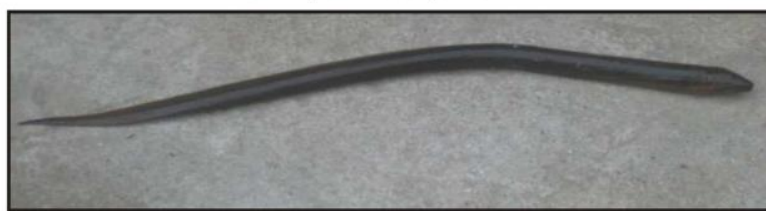

98. Monopterus cuchia

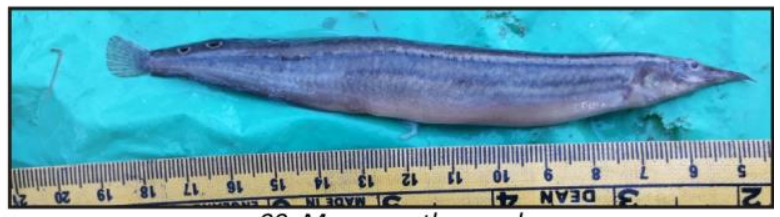

99. Macrognathus aral

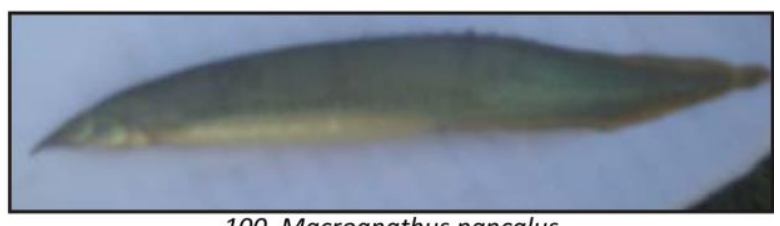

100. Macrognathus pancalus 
Subba, Pokharel and Pandey / Our Nature (2017), 15(1-2): 55-67

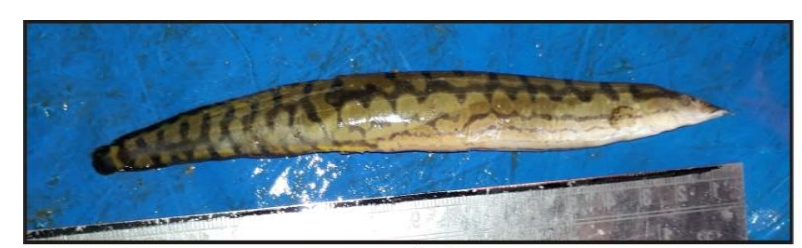

101. Mastacembelus armatus
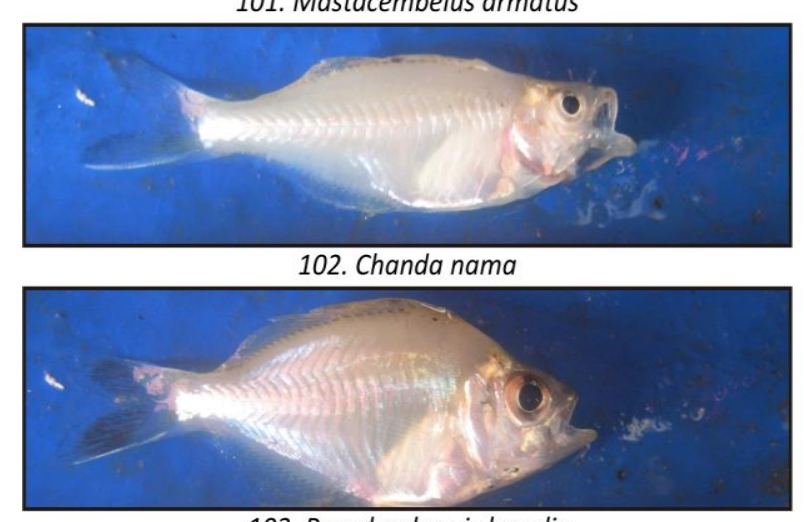

103. Pseudambassis baculis

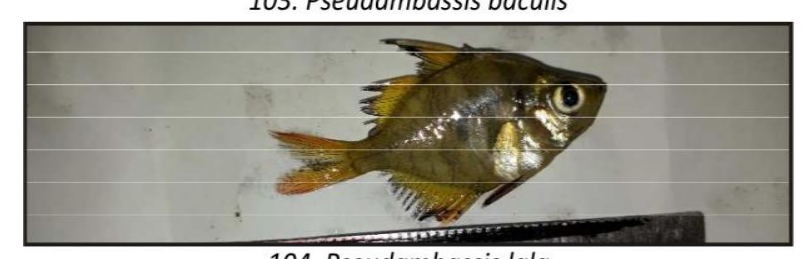

104. Pseudambassis Iala

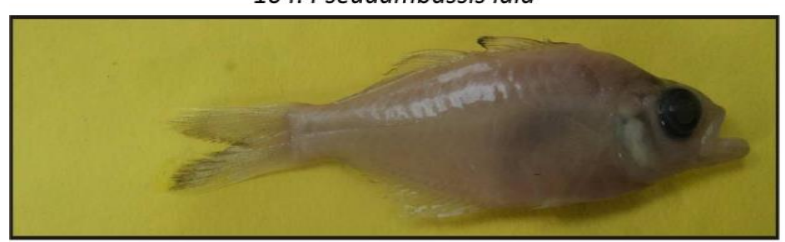

105. Pseudambassis ranga

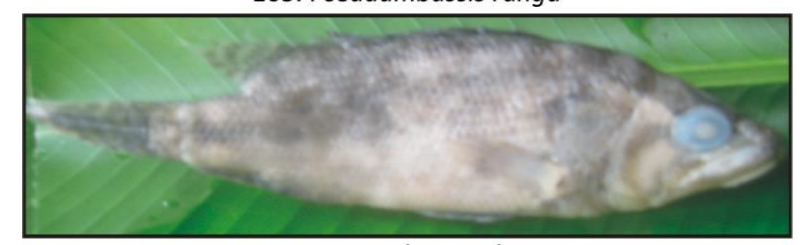

106. Nandus nandus

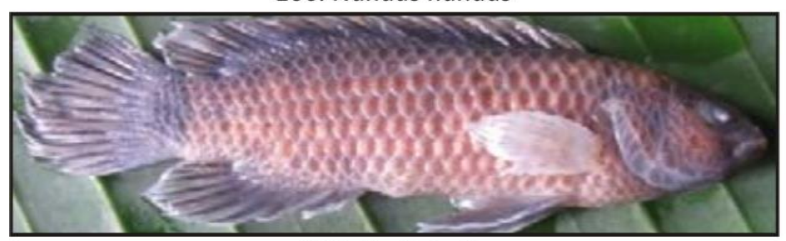

107. Badis badis

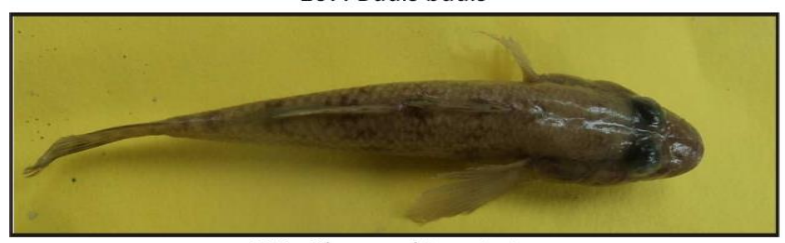

108. Glossogobius giurius

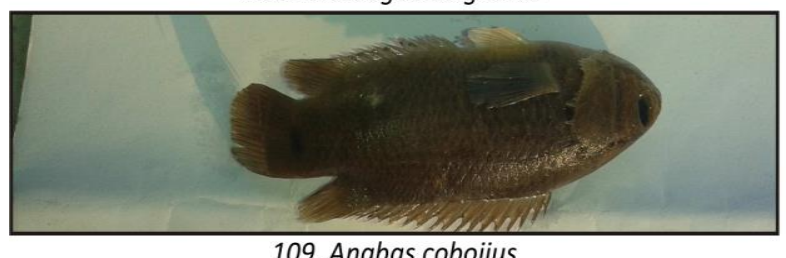

109. Anabas cobojius
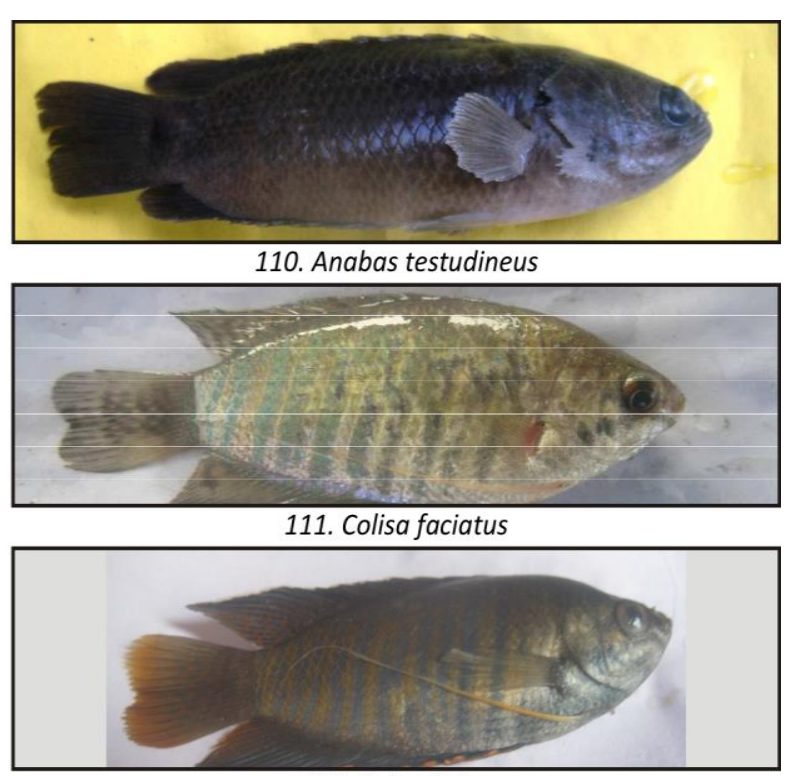

112. Colisa Ialius

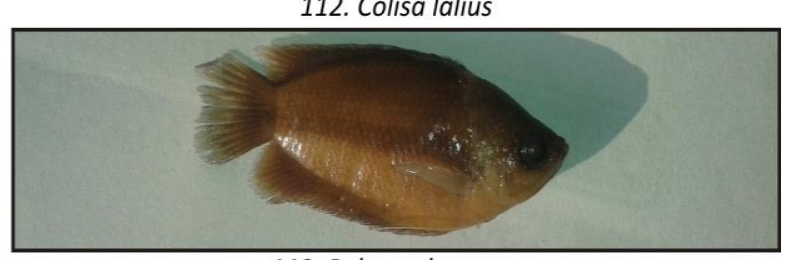

113. Polycanthus sota

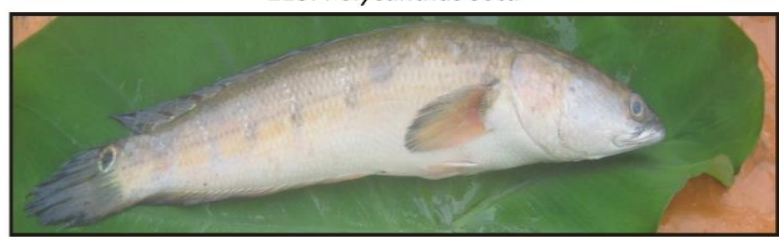

114. Channa marulius

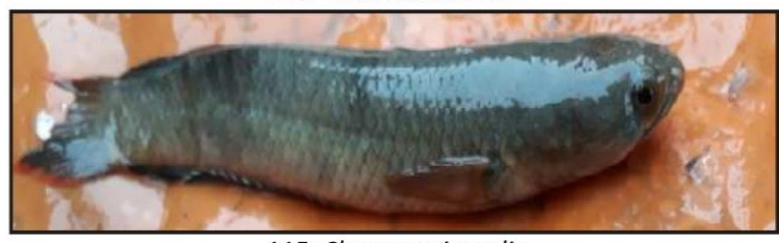

115. Channa orientalis

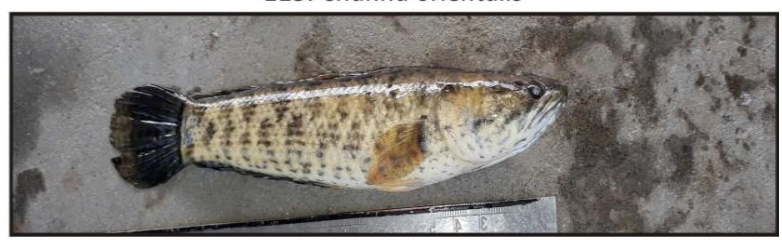

116. Channa punctatus

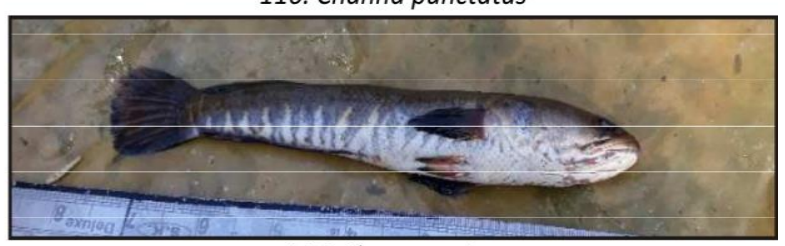

117. Channa striatus

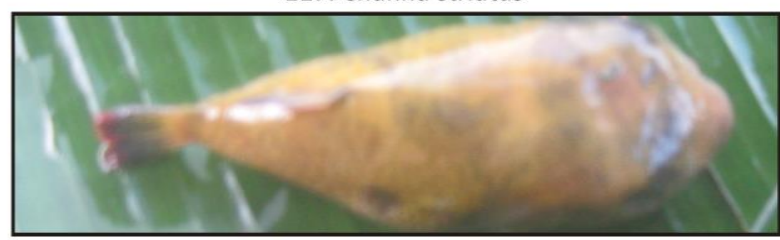

118. Tetradon cutcutia

Figure 2. Fishes of Morang district. 
Edds, D.R. 2007. Fishes in Nepal: Ichthyofaunal surveys in seven nature reserves. Ichthyological Exploration of Freshwaters 18(3): 277.

Giri, M.K. 1992. Fauna of Arun Basin of East Nepal. J. Nat. Hist. Mus. 1(2): 12-14.

Günther, A.G. 1861. List of the cold-blooded vertebrata collected by B.H. Hodgson, Esq., in Nepal. Proc. Zool. Soc. London, pp. 213227.

Hamilton, F.B. 1822. An accountant of the fishes found in the river Ganges and its branches. Printed for A. Constable and Company. pp. 7,405

Hickel, B. 1979. Limnological investigation in lakes of Pokhara Valley, Nepal. Int.Revue Gea. Hydrobil. 58: 659-672.

Hora, S.L. 1921. On some new or rare species of fish from the eastern Himalayas. Records of the Indian Museum 22: 731-744.

Jha, D.K. and T.K. Shrestha 1986. Fish fauna of Karnali River. J. Inst. Agri. Anim. Sci. 7: 5161.

Kachari, A., B. Gogoi, R. Dutta, K. Aran, P. Ghosh, S. Maitra, S. Bhattacharya and D.N. Das 2014. Habitat preference of an endangered Hill Stream Catfish Olyra longicaudata (McClelland) from Arunachal Pradesh, India. Int. J. Fish. Aquat. Stud. 1: 86-93.

Lakra, W.S., U.K. Sarkar, A. Gopalakrishnan and A.K. Pandian 2010. Threatened freshwater fishes of India. NBFGR, Lucknow.

$\mathrm{Ng}$, H.H. 2003. A revision of the south Asian sisorid catfish genus Sisor (Teleostei: Siluriformes). J. Nat. Hist. Mus. 37(23): 2871-2883.

Niroula, L.P. and B.R. Subba 2004. Fish diversity of Kankai River with reference to Jhapa district, Nepal. Book of Abstracts of Natural Resources Management, Feb. pp. 13-14.

Petr, T. and D.B. Swar (ed.) 2002. Cold water fisheries in the Trans-Himalayan countries. FAO Fisheries Technical Paper. No. 431 Rome, FAO. 376p.

Rajbanshi, K.G. 2012. Biodiversity and distribution of freshwater fishes of Central/Himalayan region. Nepal Fisheries Society, Kathmandu. 65p.

Shrestha, J. 1981. Fishes of Nepal. Curriculum Development Centre. Tribhuvan University, Kathmandu, Nepal.

Shrestha, J. 2013.Biodiversity of fish appeared in (biological diversity and conservation). Nepal Academy of Science and Technology (NAST) Kathmandu, Nepal. Nepalpedia series No. 2.

Shrestha, T.K. 1990. Rare fishes of Himalayan waters of Nepal. Journal of Fish Biology 37: 213-216. Supplement Academic Press, London.

Shrestha, T.K. 2008. Ichthyology of Nepal: A study of fishes of the Himalayan waters. Himalayan Ecosphere. 388p.

Subba, B.R. 1995. Report on the occurrence of a hill stream fish, Olyra longicaudata (McClelland, 1842), Siluriformes, Olyridae from Kadya River of Nepal. Freshwater Biol. 7(2): 155-157.

Subba, B.R. and T.K. Ghosh 1996. A new record of the pigmy barb Puntius phutunio (Ham.) from Nepal. Freshwater Biol. 8(3): 159-161.

Taft, A.C. 1955. A survey of fisheries in Nepal, both present and potential. ITOICA 94, Kathmandu. 32p.

Talwar, P.K. and A.G. Jhingran 1991. Inland fishes of India and adjacent countries. Vol. I and II. Oxford and IBH Publishing Co. Pvt. Ltd.

Terashima, A. 1984. Three new species of the cyprinid genus Schizothorax from Lake Rara, North-Western, Nepal. Japanese J. Ichthyol. 31(2): 122-135. 